\title{
Social Skills in Children and Adolescents: Differences Between Deaf and Hearing
}

\author{
Rafaela Fava de Quevedo ${ }^{1}$ \\ Ilana Andretta ${ }^{1}$
}

\begin{abstract}
Deafness results in difficulties in identifying elements of social performance in other people. This study evaluated the social skills of deaf and hearing children and adolescents to draw a profile on the categories of social skills. This is a quantitative, crosssectional, comparative study. The participants were 122 deaf and hearing children and adolescents, each group containing 61 individuals aged between 7 and 16 years. The instruments used were a sociodemographic questionnaire and the Teste de Habilidades Sociais para Crianças e Adolescentes em Situação Escolar (THAS-C). The results showed deficits in the social skills of deaf children and adolescents compared to hearing. The social skills profiles generally favored the hearing groups, with the exception of the item Conversation and Social Resourcefulness, which favored deaf children. Communicational and developmental differences were considered during the discussion. We stress the need for research with deaf individuals to propose interventions adapted to this population.
\end{abstract}

Keywords: social skills, hearing disorders, evaluation

\section{Habilidades Sociais em Crianças e Adolescentes: Diferenças entre Surdos e Ouvintes}

\begin{abstract}
Resumo: A surdez repercute em dificuldades na identificação de elementos de desempenho social das outras pessoas. Este estudo teve como objetivo avaliar as habilidades sociais de crianças e adolescentes surdos e ouvintes e traçar um perfil discriminante sobre categorias de habilidades sociais. Trata-se de um estudo quantitativo, transversal, comparativo. Os participantes foram 122 surdos e ouvintes, 61 em cada grupo, com idade entre 7 e 16 anos. Os instrumentos utilizados foram um questionário sociodemográfico e o Teste de Habilidades Sociais para Crianças e Adolescentes em Situação Escolar. Os resultados apontaram déficits nas habilidades sociais de crianças e adolescentes surdos quando comparados aos ouvintes. Os perfis de habilidades sociais discriminaram em favor dos grupos de ouvintes, com exceção do item Conversação e Desenvoltura Social, que discriminou em favor das crianças surdas. Considerou-se as diferenças comunicacionais e desenvolvimentais no decorrer da discussão. Salienta-se a necessidade de pesquisas com surdos para propor intervenções adaptadas a esta população
\end{abstract}

Palavras-chave: habilidades sociais, distúrbios da audição, avaliação

\section{Habilidades Sociales en Niños y Adolescentes: Diferencias entre Sordos y Oyentes}

\begin{abstract}
Resumen: La sordera resulta en dificultades para identificar elementos del desempeño social de otras personas. Este estudio tuvo como objetivo evaluar las habilidades sociales de niños y adolescentes sordos y oyentes, e identificar un perfil de discriminación acerca de las categorías de habilidades sociales. Este es un estudio cuantitativo, transversal y comparativo. Participaron 122 sordos y oyentes, distribuidos 61 en cada grupo, con edades entre 7 y 16 años. Se utilizaron un cuestionario sociodemográfico y la Prueba de Habilidades Sociales para Niños y Adolescentes en Situación Escolar. Los resultados mostraron déficits en las habilidades sociales de niños y adolescentes sordos comparados a los oyentes. Los perfiles de habilidades sociales discriminaron a favor de los grupos de oyentes, con la excepción del ítem Conversación y Desarrollo Social, que discriminó a favor de los niños sordos. Se consideró las diferencias de comunicación y de desarrollo durante la discusión. Se destaca la necesidad de más estudios con la población sorda para proponer intervenciones adaptadas a esta población.
\end{abstract}

Palabras clave: habilidades sociales, trastornos de la audición, evaluación

\footnotetext{
${ }^{1}$ Universidade do Vale do Rio dos Sinos, São Leopoldo-RS, Brazil

Article derived from the master's dissertation of the first author under the supervision of the second, defended in 2018, for the Graduate Program in Clinical Psychology of Universidade do Vale do Rio dos Sinos - UNISINOS.

Correspondence address: Rafaela Fava de Quevedo. Universidade do Vale do Rio dos Sinos. Avenida Unisinos, 950, Cristo Rei, São Leopoldo-RS, Brazil. CEP 93.022-000. E-mail: rafaelafaq@msn.com
}

Social skills are constructs wherein the individual expresses adaptive behaviors in interpersonal situations about ways of expressing opinions, attitudes, facing criticism, defending rights related to oneself and others (Z. A. P. Del Prette \& A. Del Prette, 2011). These skills are conceptualized on the basis of the social behavior of a given 
culture, contributing to a socially competent performance in interpersonal development (A. Del Prette \& Z. A. P. Del Prette, 2017). Thus, social skills are learned and developed as we are inserted in social interactions, which involve verbal and non-verbal behavior and concern the behavior emitted in a certain social situation (A. Del Prette \& Z. A. P. Del Prette, 2017; Matson, 2017).

Considering the behavior relative to the dimensions of social abilities, according to Bartholomeu, Silva and Montiel (2014), these can be subdivided into three factors. With regard to the first factor, Civility and Altruism, the skills of making and accepting compliments, apologizing, helping friends, expressing positive feelings and education when expressing opinions are considered. As for the second factor, Conversation and Social Resourcefulness, the indicators are related to exposure to new situations that may impact on embarrassment, such as receiving criticism, speaking in public and presenting oneself to an unknown person. For the third factor, Assertiveness with Confronting, questions related to expressing displeasure, defending rights and opinions, resisting group pressure and affirming self-esteem are estimated.

Social skills are learned while in social contexts in which individuals are situated. An explanation to learning social behavior is understood by the modeling factor (Matson, 2017). It is defined as learning by observing the models with which the child spends most time (Matson, 2017). However, regarding hearing impairments, there is greater difficulty in identifying components of interaction and social performance of other people, as these involve verbal and non-verbal linguistic components of social competence. Thus, limitations in these characteristics can be obstacles to the ability to identify the demands of the social context, as well as in achieving expected performance, since there is a sensory deprivation that hinders the level of proficiency of these behaviors (Z. A. P. Del Prette \& A. Del Prette, 2011).

The sense of hearing fundamentally facilitates communication and, as a consequence, promotes interaction between a person and their surrounding environment. On the other hand, being deprived of this sense can lead to losses in these areas (World Health Organization [WHO], 2016). Deaf people suffer with severe or deep hearing loss, which implies hearing little to no sound. The term deafness is equivalent to different nomenclatures, such as, for example, hearing loss and hearing impairment. What changes in these definitions is the degree of damage that exists regarding the quality and amplitude of sound, measured in decibels (WHO, 2016). It is estimated that 360 million people (about $5 \%$ of the world's population) live with some type of hearing loss, of which almost 32 million are children (WHO, 2016). One of the means of communication is through the gesturevisual modality, and in Brazil the deaf use the Brazilian Sign Language-Libras (Martins, 2012).

Considering studies on the subject, we highlight the contribution of Bradway (1937), who conducted an American research on the social competence of 92 institutionalized deaf people aged five to 20 years. This study presented delays of $20 \%$ in the social competence of these deaf people in relation to their age compared to the validation of the instrument, called Vineland Social Maturity Scale, for listeners. It should be noted that this is one of the first works published on the subject and has limitations, such as not explaining whether they were deaf or used sign language.

However, Streng and Kirk (1938), replicated the study by Bradway (1937) with 97 deaf, non-institutionalized oralized children aged 6-18 years, using the same assessment instrument. In contrast to the results by Bradway (1937), Streng and Kirk (1938) claim that there are no differences in social competence between deaf and hearing individuals. The authors state that such differences may be due to the fact that children participating in the Bradway study are in residential schools, in the context of institutionalization, while the children in their study live with their families and the school is attended during working days of the week, and this difference may be a causal factor for better social skills (Streng \& Kirk, 1938). In the same sense, Vogel-Walcutt, Schatschneider and Bowers (2011) evaluated the social skills of 20 deaf children and adolescents compared to 20 hearing individuals of the same age group, noting that there were no significant differences in the social skills of these groups. However, the authors highlight that the sampling numbers make generalizations impossible.

Bobzien et al. (2013), in a study conducted with eight deaf children in the context of inclusion, concluded that these children have less initiative in communication compared to hearing peers, however, they show themselves as engaged in the participation of the play. In other words, in the context of deafness, sociocognitive development depends on adaptive communicational interactions, assisting in more skilled social behaviors. Freitas and Del Prette (2014) conducted a study to identify social skills in children with different disabilities. Although the group of deaf children $(n=10)$ showed no differences compared to other groups of disabilities, the study suggests that these children would benefit from training programs for developing social skills, considering their differences in development. In another recent study (Hoffman, eyebrows, \& Quittner, 2016), the language delay of deaf children is a factor that is associated with the deficit in social competence compared to their listening peers.

Although the aforementioned studies have been presented, the literature indicates a gap in the evaluation of social skills in minority groups and sensory impairments (Z. A. P. Del Prette \& A. Del Prette, 2011; Freitas \& Del Prette, 2014), mainly since they present interpersonal difficulties as their own characteristics, having their social autonomy impaired by belonging to a certain group (Z. A. P. Del Prette \& A. Del Prette, 2011). Casalli and Costa (2017) affirm the need for studies that evaluate the social skills of deaf children and adolescents, users of Libras who attend a bilingual school, as none of the studies presented include this particularity. The field of disabilities should be understood while taking into account the process of belonging, in search of rehabilitation strategies so that these people may adapt better compared to those defined as normal (Piccolo \& Mendes, 2013). 
Based on deafness and the implications addressed by the literature, it can be seen that the evaluation of social skills can help in the development of clinical psychology, as well as in possible educational measures in a school context for students and/or teachers. The identification of specific deficits and resources in social skills can subsidize the planning of future interventions for this specific audience, also providing opportunities for contributions to the evaluation and intervention in social skills. As such, this study evaluated the social skills of deaf and hearing children and adolescents and to draw a profile on categories of social skills.

\section{Method}

\section{Participants}

This is a quantitative, cross-sectional, comparative study (Field, 2016). The sample consisted of 122 children and adolescents aged seven to 16 years divided into two groups, a group of deaf individuals $(n=61)$ and a group of hearing individuals $(n=61)$, paired for age and gender and balanced regarding level of education. In both groups, the following inclusion criteria were established by age group: participants aged seven to 11 years belonged to the group of children $(n=46)$; and participants aged 12 to 16 years were included in the group of adolescents $(n=76)$. The mean age of the children group was $8.91(S D=1.41)$, and $52.2 \%(n=24)$ were male. As for the participants included in the group of adolescents, mean age was 13.61 years $(S D=1.44)$, and $68.4 \%(n=52)$ were female. Of the 122 participants, $78.7 \%(n=96)$ had siblings and $21.6 \%(n=26)$ were single children. In the deaf group, the majority $(86.9 \%, n=53)$ did not use a cochlear implant, while the rest $(13.1 \%, n=8)$ used unilateral cochlear implant.

The participants were enrolled in public schools in the Metropolitan Region and Serra Gaúcha, and for the deaf group, the four participating schools used the teaching modality and gesture communication by Libras or bilingualism (Libras and written Brazilian Portuguese). Representing the initial grades of Elementary School (1st to 5 th grade), the sample consisted of $37.7 \%(n=46)$ of these participants. As for the final grades of Elementary School (6th to 9th grade), the sample consisted of $54.9 \%(n=67)$ participants, and representing High School, the sample presented $7.4 \%(n=9)$ of participants. Most participants studied at the same school $(54.1 \%, n=66)$ and never failed $(80.3 \%, n=98)$. It is worth noting that children and adolescents who had another medical diagnosis or syndrome that could be used as cognitive impairment were excluded from the sample. This information would be confirmed by the child's guardian who contributed with the completion of the sociodemographic questionnaire. The majority of those responsible were parents $(94.3 \%)$ or grandparents $(5.7 \%)$, with a mean age of 40.20 years $(S D=8.59)$. As for the assessment of socioeconomic level (Associação Brasileira de Empresas de Pesquisa [ABEP], 2016), most families belong to the socioeconomic classes C, D-E, represented by $62.3 \%(n=76)$ of the sample.

\section{Instruments}

Sociodemographic questionnaire. It serves specifically to know the characteristics of the sample population, such as age, gender, education and history of disapproval, socioeconomic classification (ABEP, 2016), diagnoses about cognitive impairment, family constitution, information about those responsible, such as age, gender, education, work, among others.

Teste de Habilidades Sociais para Crianças e Adolescentes em Situação Escolar (THAS-C). This is a selfreport instrument that evaluates the social skills of children from seven to 15 years of age, however, the authors also applied it to adolescents of 16 years (Bartholomeu et al., 2014). Evidence of the psychometric qualities validating the instrument was demonstrated by Bartholomeu, Silva and Montiel (2011), using factor analysis. The THAS-C is a threepoint Likert scale composed of 23 items that evaluate three distinct factors: Factor 1 evaluates categories of behavior related to Civility and Altruism (13 items); Factor 2 evaluates items related to Conversation and Social Resourcefulness (six items); Factor 3 evaluates the set of social behaviors indicative of Assertiveness with Confronting (four items). For each item three answers are available, "Always" (2), "Sometimes" (1), and "Never" $(0)$. The gross and total score is transposed into percentiles, rendering classifications ranging from very low social ability (quartile below 25) and very high social ability (quartile above 75). The accuracy coefficients of the scale provided reliability indices of 0.83 for Cronbach's Alpha considering the three factors and the general classification of social abilities (Bartholomeu et al., 2014). For the present study, the alpha value was 0.71 , showing sensitivity for this population and for the proposed objectives.

The adaptation of the instrument to Libras took place with a translator/interpreter of Libras, as deaf people have the right to be evaluated in their official language. In order to make the instrument more comprehensive, a suggestion by a deaf pedagogue was followed and we adapted the content to Libras, considering the use of more concrete signs for younger children, since the period between seven and 16 years is important for the construction of visualgestural language. We note that this care avoids distortions in communication and the occurrence of biases, and is also a way to respect the cultural identity of the deaf individual (Andrade \& Castro, 2016).

\section{Procedure}

Data collection. Special educational institutions for the deaf and regular education were contacted by telephone and/ or by e-mail. In most schools, the management team sent an Informed Consent Form (ICF) and the sociodemographic questionnaire to the families. A rapport was conducted with each child and adolescent, the consent form was signed, 
and the social skills assessment instrument was applied individually in the form of an interview, lasting between 15 and 30 minutes, in a room provided by the schools. During this process, participants were informed about the protection and confidentiality of their information. It should be noted that data collection involving the deaf participants was carried out together with a Librass translator/interpreter.

Data analysis. The data were analyzed using the software Statistical Package for the Social Sciences [SPSS], v. 22.0 (IBM, 2015), considering a significance level of $5 \%$. Descriptive analyses were performed through absolute and relative distribution $(n / \%)$, including mean, standard deviation and amplitude. Based on inferential statistics analysis, the homogeneity of the sample was verified by the Kolmogorov-Smirnov test. Thus, we chose Student's $t$ test to compare independent groups between deaf and hearing children and adolescents.

To trace the discriminant profile between deaf and hearing children and adolescents, discriminant analysis was performed using the stepwise method. This modality of statistical analysis applies in situations where the sample can be divided into groups based on a dependent variable. The objectives of this analysis are to verify the differences between groups in order to predict the probability of an individual belonging to a particular group or profile based on the independent variables (Hair, Black, Babin, Anderson, \& Tatham, 2009). This way, factors of social skills most statistically associated with the group of deaf participants (profile estimation sample) and the group of hearing participants (validation sample) were indicated. During analysis, the characteristic of being deaf or able to hear, even if not manipulated, was considered a profile instead of a variable. On the other hand, social skills were considered independent variables.

\section{Ethical Considerations}

This study was approved by the Research Ethics Committee of UNISINOS, under Opinion No. 1,917,775 (CAAE No. 62681816.2.0000.5344). In order to have access to the children and adolescents of the survey, parents or guardians signed the ICF, and each participant signed the consent form. Both documents contained information about the search and guaranteed the confidentiality of personal information.

\section{Results}

The results were organized as follows: variables were initially compared for the groups of hearing and deaf by the $t$ test. Then, discriminant analysis was performed, verifying profiles of specific social skills of each analyzed group. Information resulting from analysis provided as follows:

In the comparison analysis between groups, the results showed that there are statistically significant differences between the groups of children who are deaf and who are able to hear with respect to two factors of social skills:
Civility and Altruism $(t=3.758 ; p=0.001)$, that is, hearing children had higher means $(M=5.17, S D=1.85)$ for this factor compared to deaf children $(M=3.00, S D=2.06)$; and General Social Skills $(t=-2.557 ; p=0.014)$, wherein hearing children had higher means $(M=4.65, S D=2.24)$ compared to deaf children $(M=3.00, S D=2.13)$.

For the group of adolescents, the results showed that there was no statistically significant difference for Civility and Altruism $(t=-2.291, p=0.025)$, the Conversation and Social Resourcefulness $(t=-3.283, p=0.002)$, Assertiveness with Confronting ( $t=-4.568, p<0.001)$, and in General Social Skills $(t=3.914, p<0.001)$, demonstrating that hearing adolescents have higher means compareto deaf adolescents for each factor described (see Table 1).

Table 1

Comparison of social skills between deaf and hearing children and adolescents

\begin{tabular}{|c|c|c|c|c|}
\hline & & Mean $(D P)$ & $t$ & $p$ \\
\hline \multicolumn{5}{|l|}{ Children } \\
\hline \multirow{2}{*}{$\begin{array}{l}\text { Civility and } \\
\text { Altruism }\end{array}$} & Deaf & $3.00( \pm 2.06)$ & \multirow{2}{*}{3.758} & \multirow{2}{*}{$0.001^{*}$} \\
\hline & Hearing & $5.17( \pm 1.85)$ & & \\
\hline \multirow{2}{*}{$\begin{array}{l}\text { Conversation } \\
\text { and Social } \\
\text { Resourcefulness }\end{array}$} & Deaf & $3.65( \pm 2.49)$ & \multirow[b]{2}{*}{-1.383} & \multirow[b]{2}{*}{0.174} \\
\hline & Hearing & $4.65( \pm 2.40)$ & & \\
\hline \multirow{2}{*}{$\begin{array}{l}\text { Assertiveness } \\
\text { with } \\
\text { Confronting }\end{array}$} & Deaf & $3.48( \pm 2.15)$ & \multirow[b]{2}{*}{0.197} & \multirow[b]{2}{*}{0.844} \\
\hline & Hearing & $3.35( \pm 2.32)$ & & \\
\hline \multirow{2}{*}{$\begin{array}{l}\text { General Social } \\
\text { Skills }\end{array}$} & Deaf & $3.00( \pm 2.13)$ & \multirow{2}{*}{-2.557} & \multirow{2}{*}{$0.014^{*}$} \\
\hline & Hearing & $4.65( \pm 2.24)$ & & \\
\hline \multicolumn{5}{|l|}{ Adolescents } \\
\hline \multirow{2}{*}{$\begin{array}{l}\text { Civility and } \\
\text { Altruism }\end{array}$} & Deaf & $5.61( \pm 1.53)$ & \multirow{2}{*}{-2.291} & \multirow{2}{*}{$0.025^{*}$} \\
\hline & Hearing & $6.32( \pm 1.14)$ & & \\
\hline \multirow{2}{*}{$\begin{array}{l}\text { Conversation } \\
\text { and Social } \\
\text { Resourcefulness }\end{array}$} & Deaf & $3.08( \pm 2.27)$ & \multirow[b]{2}{*}{-3.283} & \multirow[b]{2}{*}{$0.002^{*}$} \\
\hline & Hearing & $4.66( \pm 1.90)$ & & \\
\hline \multirow{2}{*}{$\begin{array}{l}\text { Assertiveness } \\
\text { with } \\
\text { Confronting }\end{array}$} & Deaf & $4.37( \pm 2.35)$ & \multirow{2}{*}{-4.568} & \multirow{2}{*}{$0.001^{*}$} \\
\hline & Hearing & $6.29( \pm 1.08)$ & & \\
\hline \multirow{2}{*}{$\begin{array}{l}\text { General Social } \\
\text { Skills }\end{array}$} & Deaf & $5.71( \pm 1.25)$ & \multirow{2}{*}{-3.914} & \multirow{2}{*}{$0.001^{*}$} \\
\hline & Hearing & $6.66( \pm 0.81)$ & & \\
\hline
\end{tabular}

In view of these differences, discriminant analysis was performed to identify social skills profiles according to age group in hearing and deaf participants. Thus, regarding the group of deaf and hearing children, Wilks $\lambda$ of 0.672 can observed, equivalent to a variance explained by the discriminant function of $48.7 \%$. Regarding the group of deaf and hearing adolescents, a Wilks $\lambda$ of 0.702 was observed, parallel to a variance explained by the discriminant function of $42.4 \%$ (Table 2). 
Table 2

Discriminant function values among deaf and hearing children and adolescents

\begin{tabular}{cccccccc}
\hline Function & Self-value & $\begin{array}{c}\text { Percentage of } \\
\text { variance }\end{array}$ & $\begin{array}{c}\text { Canonical } \\
\text { Correlation }\end{array}$ & Wilks $\lambda$ & $\chi^{2}$ & $D F$ & $p$ \\
\hline$l a$ & $0.487^{\mathrm{a}}$ & 100.0 & 0.572 & 0.672 & 17.264 & 1 & 0.001 \\
$1 b$ & $0.424^{\mathrm{b}}$ & 100.0 & 0.546 & 0.702 & 25.803 & 1 & 0.001 \\
\hline
\end{tabular}

Note. Eigenvalues of the function obtained 1a. for the group of children and $1 \mathrm{~b}$. for the group of adolescents.

Regarding the classification for the group of children, the obtained function correctly classified $76.1 \%$ of participants in the respective groups and classified $76.3 \%$ of the group of adolescents, both presenting themselves as having a good index for predicting the profile of the obtained function (Table 3).

Table 3

Discriminant classification values among deaf and hearing children and adolescents

\begin{tabular}{ccccc}
\hline \multirow{2}{*}{$\begin{array}{c}\text { Child or } \\
\text { adolescent }\end{array}$} & $\begin{array}{c}\text { Deaf or hearing } \\
\text { participant }\end{array}$ & \multicolumn{2}{c}{ Association to group } & \multirow{2}{*}{ Total } \\
\cline { 3 - 4 } Child & Deaf & $82.6 \%$ & $17.4 \%$ & \\
& Hearing & $30.4 \%$ & $69.6 \%$ & $100 \%$ \\
& Deaf & $76.3 \%$ & $23.7 \%$ & \\
Adolescent & Hearing & $23.7 \%$ & $76.3 \%$ & \\
\hline
\end{tabular}

Note. Classification of groups - Child $=76.1 \%$ of original cases were correctly classified; Adolescent $=76.3 \%$ of original cases were correctly classified.

The group of deaf children presented a centroid value of -0.683 , while the group of hearing children presented a centroid value of 0.683 . The group of deaf adolescents had a value of -0.643 , while the group of hearing adolescents had a centroid value of 0.643 . These values indicate that the groups are well separated by the obtained profile and can be discriminated by the variables presented, wherein the sign of the correlations obtained indicates a direction favorable to one group or another. The variables discriminated between the age groups child and adolescent and between deaf and hearing participants are ordered by absolute correlation size in the structural matrix, with a cutoff point of 0.100 (Table 4).

The social skills categories were distinguished between groups, as shown in Table 4. The skills that most discriminated the group of children were Civility and Altruism (1.000) and general social skills $(0.765)$ in favor of the group of hearing children, and the categories that most discriminated against the group of adolescents were General Social Skills (0.902) and Conversation and Social Resourcefulness (0.616), in favor of the group of hearing adolescents. With moderate power of discrimination between groups of deaf and hearing children, there are the categories of Assertiveness with Confronting (0.374) favoring hearing children and Conversation and Social
Resourcefulness (-0.164) favoring deaf children. Differently, the group of deaf and hearing adolescents presented moderate power in the categories Assertiveness with Confrontation (0.529) and Civility and Altruism (0.385), both favoring the group of hearing adolescents.

In summary, the group of hearing children presented a profile related to the social skills of Civility and Altruism, Assertiveness with Confronting and General Social Skills, and only the category Conversation and Social Resourcefulness favored deaf children. On the other hand, for the group of adolescents, a profile was found wherein all social skills items analyzed were directed to the hearing participants. These results are discussed considering social skills, age development and the specificities of deafness.

Table 4

Social skills discriminated between deaf and hearing children and adolescents

\begin{tabular}{ccc}
\hline & $\begin{array}{c}\text { Function 1 } \\
\text { Children: } \\
\text { Deaf and hearing }\end{array}$ & $\begin{array}{c}\text { Function 1 } \\
\text { Adolescents: Deaf } \\
\text { and hearing }\end{array}$ \\
\hline $\begin{array}{c}\text { Civility and Altruism } \\
\text { Conversation } \\
\text { and Social }\end{array}$ & 1.000 & 0.385 \\
Resourcefulness & -0.164 & 0.616 \\
$\begin{array}{c}\text { Assertiveness with } \\
\text { Confronting } \\
\text { General Social } \\
\text { Skills }\end{array}$ & 0.374 & 0.529 \\
\hline
\end{tabular}

Note. Structural matrix of the discriminant canonical function. Positive functions are directed to hearing individuals, and negative functions are directed to deaf individuals in both groups.

\section{Discussion}

Research in Brazil linked to the field of social skills is mainly carried out with children and adolescents (BolsoniSilva et al., 2006), in the same way as the participants of the present study, whose age group was 7-16 years. Given the differences between the deaf group and the hearing group, the hypothesis that there are deficits in social skills in deaf children and adolescents compared to their hearing peers was confirmed. This hypothesis corroborates studies that have shown similar results (Bobzien et al., 2013; Bradway, 1937; Hoffman et al., 2016). On the other hand, it is known that deaf people are a linguistic minority (Martins, 2012), which 
means that the differences arising between deaf and hearing individuals can increase as they belong to two different cultures, which differ both by in the matter of language and in specific matters (exclusion, social segregation and limitations). However, this result contradicts strong and Kirk (1938) and Vogel-Walcutt et al. (2011). Thus, these differences in the development of a deaf child might be the cause of such deficits, especially since interaction can be limited and the quality of acquisition of social models might be reduced (Marschark, 2018; Matson, 2017), possibly leading to limitations in communication (Gianoto, Gianotto, \& Marques, 2016), since the deaf participants of this research come from hearing families.

In the case of the difference between groups regarding Civility and Altruism, it stands out as a subclass of social skills that comprises social behaviors that reflect kindness, such as greeting people, making and accepting compliments, asking and answering questions, among others (Bartholomeu et al., 2014; A. Del Prette \& Z. A. P. Del Prette, 2017). The skills of Civility and Altruism are presented as basic strategies for acceptance in a culture or group. Differences between cultures can be identified by verifying the form of these skills, that is, there may be ignorance or previous failure in social learning within the groups individuals participate, either by inadequate models, social isolation or restricted coexistence to a certain type of culture (Z. A. P. Del Prette \& A. Del Prette, 2011; Semrud-Clikeman, 2007).

In view of this perspective and considering that the deaf population lives between two cultures (hearing and deaf), this difference between groups can be explained by the fact that a deaf child, after birth and participating in a hearing family, is restricted to learning social skills with failures, especially due to differences in communication and limited exposure to social models that consequently lead to degrees of social isolation within the family itself (Karnopp, Klein, $\&$ Lunardi-Lazzarin, 2011). In any case, the coexistence and transition between these cultures can also be a factor that explains the difference between deaf and hearing groups. Still, deafness alone might hinder the process of socialization, especially due to the inability to hear sounds (WHO, 2016). This difficulty increases especially in the case of the deaf individual coming from a hearing family, as it can hinder interaction and communication and, consequently, infer in the modeling of identification and social behaviors (Gianoto et al., 2016).

Considering the differences between groups of deaf and hearing adolescents for Conversation and Social Resourcefulness, the result corroborates the data by Bobzien et al. (2013), which states a lower initiative in communication among deaf people compared to hearing people. Another factor is the fact that the deaf participants in this sample come from hearing families. That is, communication is delayed and filled with challenges, as their guardians do not master sign language. It is worth noting that this factor can compromise the acquisition and performance of social skills (Semrud-Clikeman, 2007). As such, these results also suggest that deaf people may avoid new social relationships, generating social isolation throughout their development period and, consequently, a reduction in quality of life (Gianoto et al., 2016).

Faced with the present risks that may be caused by deficits in conversation and social resourcefulness, discriminant analysis indicated that deaf children presented a profile directed to these skills. However, it should be noted that these were measured based on affirmations with inverse scores, denoting that the values were directed to behaviors issued with low classification in terms of social skills. In addition, this specific skill set presents a higher degree of difficulty, since it involves moral components and greater emotional regulation (Bartholomeu et al., 2014). Given this context and considering that the acquisition of communication in deaf children may be later compared to hearing children, this deficit is considered to be specifically articulated because of this delay (Gianoto et al., 2016; Marschark, 2018).

Limitations regarding the socialization of deaf individuals are also conceived, since only fairly recently schools deaf people attended focused on oralizing them or training them for lip reading (Martins, 2012). Currently, being in a bilingual school for deaf people minimizes these difficulties, since sign language is the natural language of deaf individuals and favors social interactions (Martins, 2012). Similarly, the processes of socialization take place in a more favorable environment as they are surrounded by a community of equals that transmit the characteristics and values of Deaf Culture based on sign language.

Assertiveness is a subclass of social skills that concerns expressing feelings of anger and displeasure, making and refusing requests, agreeing or disagreeing with opinions, defending one's own rights, among others, with use of effective confronting (Z. A. P. Del Prette \& A. Del Prette, 2011). The socially competent performance of assertiveness interacts with how something is said, as well as with the occasion or context in which it is uttered (A. Del Prette \& Z. A. P. Del Prette, 2017; Semrud-Clikeman, 2007). Thus, the environments in which the child or adolescent participates are crucial for the development and improvement of assertiveness. The result of the comparison between groups showed that only adolescents had differences for this factor, while there was no statistically significant difference for deaf children compared to hearing children. In such scenario, assertive behaviors are evidenced according to living experience in different situations. Thus, there are important developmental differences to be stressed, since deaf children is exposed to fewer situations where they have to behave assertively, while adolescents were already allowed to experience a greater number of situations that required socially assertive behavior, in addition to having a higher number of social relationships and interactions than children. In addition, communicational repertoire increases with age and the constancy in interpersonal relationships with their deaf peers.

Participation in bilingual school for deaf children provides them contact with sign language, which is also a space for building identities. Therefore, this recognition of identity serves as a basis for deaf individuals to strengthen themselves, establishing sources of social relations with 
their peers and with the world (Martins, 2012). Also, the differences that appeared in the comparison between deaf adolescents and the group of hearing adolescents may be associated with factors presented in the literature, such as the school environment valuing conformism (Z. A. P. Del Prette \& A. Del Prette, 2011). When assertiveness begins to be devalued or neglected, a negative association can occur on the part of children and adolescents regarding their assertive performance in relation to the authoritarianism of teachers or management team (A. Del Prette \& Z. A. P. Del Prette, 2017). That is, it may occur that the school environment reinforces issues related to compliance, which can then lead to the decline of assertive behaviors regarding the search for equal rights and how to fight and defend themselves adequately. Reciprocity, as well as an understanding of rights and duties, is an important requirement for assertiveness (Z. A. P. Del Prette \& A. Del Prette, 2011; Matson, 2017). Therefore, being deaf in the midst of hearing authorities can be a stigma and unbalance relations of reciprocity, or change how deaf adolescents perceive their rights and duties compared to others they interact with.

The results of the discriminant analysis showed that the groups of hearing children and adolescents have profiles focused on social skills and their subclasses, and the group of deaf children and adolescents again presented deficits in these skills, corroborating the comparative analysis between groups. Thus, it is important that these skills are developed for deaf groups, based on social skills training, since social behavior is considered a protective factor for people with disabilities.

The main limitations of this study are due to the application of only one evaluative measure, which was translated into Libras and performed in the presence of an interpreter. The instrument used was built for behaviors of hearing people, and changes would be necessary to allow for expressions and social behaviors of deaf individuals. The need for these skills to be evaluated by multiple informants is another limitation of this study. In addition, selfreporting tools have benefits, such as quick application and highlighting the importance of the respondent's perception. However, they have limitations, such as the ease of omitting or manipulating answers according to what the respondent imagines to be the best for themselves. In addition, there is a need to use instruments that assess cognitive deficits more accurately since this may be an important variable to qualify the results. In the present study, we chose to include in the sociodemographic questionnaire a question regarding comorbidities beyond deafness, and the guardians of all participants indicated no impairment in mental development, syndromes or disorders that function as cognitive deficit. It is known that this data can be manipulated by respondents due to the difficulty in accepting that their child would have some degree of cognitive impairment. However, it is worth noting that this study advanced the investigation of the repertoire of social skills available for deaf children and adolescents compared their hearing peers. The analyses together with studies corroborated by the literature provided knowledge about the characterization of deficits in social skills in minority groups. Thus, preventive and interventional measures are also identified as necessary for the development of these skills in a school environment that have limitations in communication, variables associated with delays in the acquisition and performance of social skills. Future studies are recommended to further the subject of social skills in deaf children and adolescents by conducting multimodal assessments, making adaptations for the specificities of this population. In addition, such evaluation could include different informants, considering the perception of those who live with these participants (family members and teachers).

\section{References}

Andrade, L. F., \& Castro, S. S. (2016). Saúde e surdez: Instrumentos de pesquisas adaptados à língua de sinais: Uma revisão sistemática [Health and hearing: Research instruments adapted to sign language: A systematic review]. Medicina (Ribeirão Preto), 49(2), 175-184. doi:10.11606/issn.2176-7262.v49i2p175-184

Associação Brasileira de Empresas de Pesquisa. (2016). Critério de Classificação Econômica Brasil [Brazilian Economic Classification Criteria]. Retrieved from http://www.abep.org/criterio-brasil

Bartholomeu, D., Silva, M. C. R., \& Montiel, J. M. (2011). Teste de habilidades sociais para crianças: Evidências psicométricas de uma versão inicial [Children's social skills test: Psychometric evidences of the initial version]. Psico-USF, 16(1), 33-43. doi:10.1590/S141382712011000100005

Bartholomeu, D., Silva, M. C. R., \& Montiel, J. M. (2014). Teste de habilidades sociais para crianças e adolescentes em situação escolar: Manual [Social skills test for children and adolescents in school situation: Manual]. São Paulo, SP: Memnon.

Bobzien, J., Richels, C., Raver, S. A., Hester, P., Browning, E., \& Morin, L. (2013). An observational study of social communication skills in eight preschoolers with and without hearing loss during cooperative play. Early Childhood Education Journal, 41(5), 339-346. doi:10.1007/s10643-012-0561-6

Bolsoni-Silva, A. T., Del Prette, Z. A. P., Del Prette, G., Montanher, A. R. P., Bandeira, M., \& Del Prette, A. (2006). A área das habilidades sociais no Brasil: Uma análise dos estudos publicados em periódicos [The area of social skills in Brazil: An analysis of studies published in journals]. In M. Bandeira, Z. A. P. Del Prette, \& A. Del Prette (Orgs.), Estudos sobre habilidades sociais e relacionamento interpessoal [Studies on social skills and interpersonal relationships] (pp. 1-45). São Paulo, SP: Casa do Psicólogo.

Bradway, K. P. (1937). The social competence of deaf children. American Annals of the Deaf, 82(2), 122-140. 
Casalli, A. C. P., \& Costa, C. S. L. (2017). Habilidades sociais de alunos surdos na perspectiva de professores da classe bilíngue, da classe comum e intérprete [Social skills of deaf students in teacher perspective of bilingual class, regular class and interpreter]. Revista Educação Especial, 30(57), 55-67. doi:10.5902/1984686X20286

Del Prette, A., \& Del Prette, Z. A. P. (2017). Competência social e habilidades sociais: Manual teórico-prático [Social competence and social skills: theoretical-practical manual]. Petrópolis, RJ: Vozes.

Del Prette, Z. A. P., \& Del Prette, A. (2011). Psicologia das habilidades sociais na infância: Teoria e prática [Psychology of social skills in childhood] (5th ed.). Petrópolis, RJ: Vozes.

Field, A. (2016). Discovering statistics using IBM SPSS Statistics (4th ed.). Thousand Oaks, CA: Sage.

Freitas, L. C., \& Del Prette, Z. A. P. (2014). Categorias de necessidades educacionais especiais enquanto preditoras de déficits em habilidades sociais na infância [Categories of special educational needs as predictors of social skills deficits in childhood]. Psicologia: Reflexão e Crítica, 27(4), 658-669. doi:10.1590/1678-7153.201427406

Gianoto, H. S. S., Gianotto, A. O., \& Marques, H. R. (2016). Pais ouvintes, filhos surdos: Barreiras na comunicação [Listeners deaf, children parents: Barriers in communication]. Multitemas, 21(49), 161-180. doi:10.20435/multi.v21i49.1114

Hair, J. F., Jr., Black, W. C., Babin, B. J., Anderson, R. E., \& Tatham, R. L. (2009). Análise multivariada de dados [Multivariate data analysis] (A. S. Sant'Anna, Trans., 6th ed.). Porto Alegre, RS: Bookman.

Hoffman, M. F., Cejas, I., \& Quittner, A. L. (2016). Comparisons of longitudinal trajectories of social competence: Parent ratings of children with cochlear implants versus hearing peers. Otology \& Neurotolology, 37(2), 152-159. doi:10.1097/MAO.00000000000938

IBM. (2015). IBM SPSS Statistics for Windows: Version 22.0. Armonk, NY: IBM Corp.

Karnopp, L. B., Klein, M., \& Lunardi-Lazzarin, M. L. (2011). Cultura surda na contemporaneidade [Deaf culture in contemporary times]. Canoas, RS: ULBRA.

Marschark, M. (2018). Raising and educating a deaf child: A comprehensive guide to the choices, controversies, and decisions faced by parents and educators (3rd ed.). New York, NY: Oxford University Press.

Martins, C. R. (2012). A cultura surda na escola [Deaf culture at school]. In G. Perlin \& M. Stumpf (Orgs.), Um olhar sobre nós surdos: Leituras contemporâneas (pp. 159-166). Curitiba, PR: CRV.

Matson, J. L. (Ed.). (2017). Handbook of social behavior and skills in children. Los Angeles, CA: Springer.
Piccolo, G. M., \& Mendes, E. G. (2013). Contribuições a um pensar sociológico sobre a deficiência [Contributions to a sociological thinking about disability]. Educação \& Sociedade, 34(123), 459-475. doi:10.1590/S010173302013000200008

Semrud-Clikeman, M. (2007). Social competence in children. New York, NY: Springer.

Streng, A., \& Kirk, S. (1938). The social competence of deaf and hard-of-hearing children in a public day-school. American Annals of the Deaf, 83(3), 244-254.

Vogel-Walcutt, J. J., Schatschneider, C., \& Bowers, C. (2011). Social-emotional functioning of elementary-age deaf children: A profile analysis. American Annals of the Deaf, 156(1), 6-22. doi:10.1353/aad.2011.0017

World Health Organization. (2016). Childhood hearing loss: Strategies for prevention and care. Geneva, Switzerland: WHO. Retrieved from http://www.who.int/ iris/handle/10665/204632

Rafaela Fava de Quevedo is a Professor of Capacitar PósGraduação, Caxias do Sul, RS, Brazil.

Ilana Andretta is a Professor at Universidade do Vale do Rio dos Sinos, São Leopoldo, RS, Brazil.

Authors 'Contribution:

All authors made substantial contributions to the conception and design of this study, to data analysis and interpretation, and to the manuscript revision and approval of the final version. All authors assume public responsibility for the content of this manuscript.

Received: Sep. 24, 2018

1st Revision: Dec. 14, 2018

2nd Revision: Mar. 11, 2019

Approved: May. 30, 2019

How to cite this article:

Quevedo, R. F., \& Andretta, I. (2020). Social skills in children and adolescents: Differences between deaf and hearing. Paidéia (Ribeirão Preto), 30, e3030.doi:https://doi.org/10.1590/1982-4327e3030 